\title{
Effect of different organic waste on cellulose-degrading enzymes secreted by Petriella setifera in the presence of cellobiose and glucose
}

\author{
Giorgia Pertile $(\mathbb{D} \cdot$ Jacek Panek (D) Karolina Oszust $(\mathbb{D})$ Anna Siczek $(\mathbb{D})$ \\ Marta Oleszek (i) - Agata Gryta (iD) Magdalena Frąc $($ i)
}

Received: 15 March 2019/Accepted: 16 July 2019/Published online: 25 July 2019

(C) The Author(s) 2019

\begin{abstract}
Cellulose degradation is less known in the Ascomycota phylum, but it is important to recognize it because this process influences the most important biochemical cycle: the carbon cycle. Cellulose degradation is carried out by a complex enzyme: cellulase. Petriella setifera has recently been recognized as a producer of cellulolytic enzymes. In this work, it was shown, that the activity of cellulose-degrading enzymes, carbon source utilization and the gene expression of $P$. setifera were not determined by pre-culturing in different lignocellulosic wastes. Moreover, it was found that the presence of glucose and cellobiose could inhibit the activity and the expression of the cellobiohydrolase enzyme. $\beta$ -
\end{abstract}

glucosidase exhibits a higher activity in all of the analysed wastes and this behaviour can be explained as a mechanism for $P$. setifera to overcome cellobioseglucose inhibition through the transglycosylation reaction. The significance of our research is to enable researchers to understand more thoroughly the cellulose degradation caused by soft rot fungus which belongs to the Ascomycota phylum. Our research is contributing to the understanding of cellulase activity and gene expression inhibition through the availability of a carbon source for $P$. setifera. Furthermore, it facilitates the acquisition of more information concerning the fungus $P$. setifera.
Electronic supplementary material The online version of this article (https://doi.org/10.1007/s10570-019-02633-4) contains supplementary material, which is available to authorized users.

G. Pertile $\cdot$ J. Panek $\cdot$ K. Oszust · A. Siczek ·

M. Oleszek · A. Gryta · M. Frąc ( ()

Institute of Agrophysics, Polish Academy of Sciences,

Doświadczalna 4, 20-290 Lublin, Poland

e-mail: m.frac@ipan.lublin.pl 


\section{Graphic abstract}

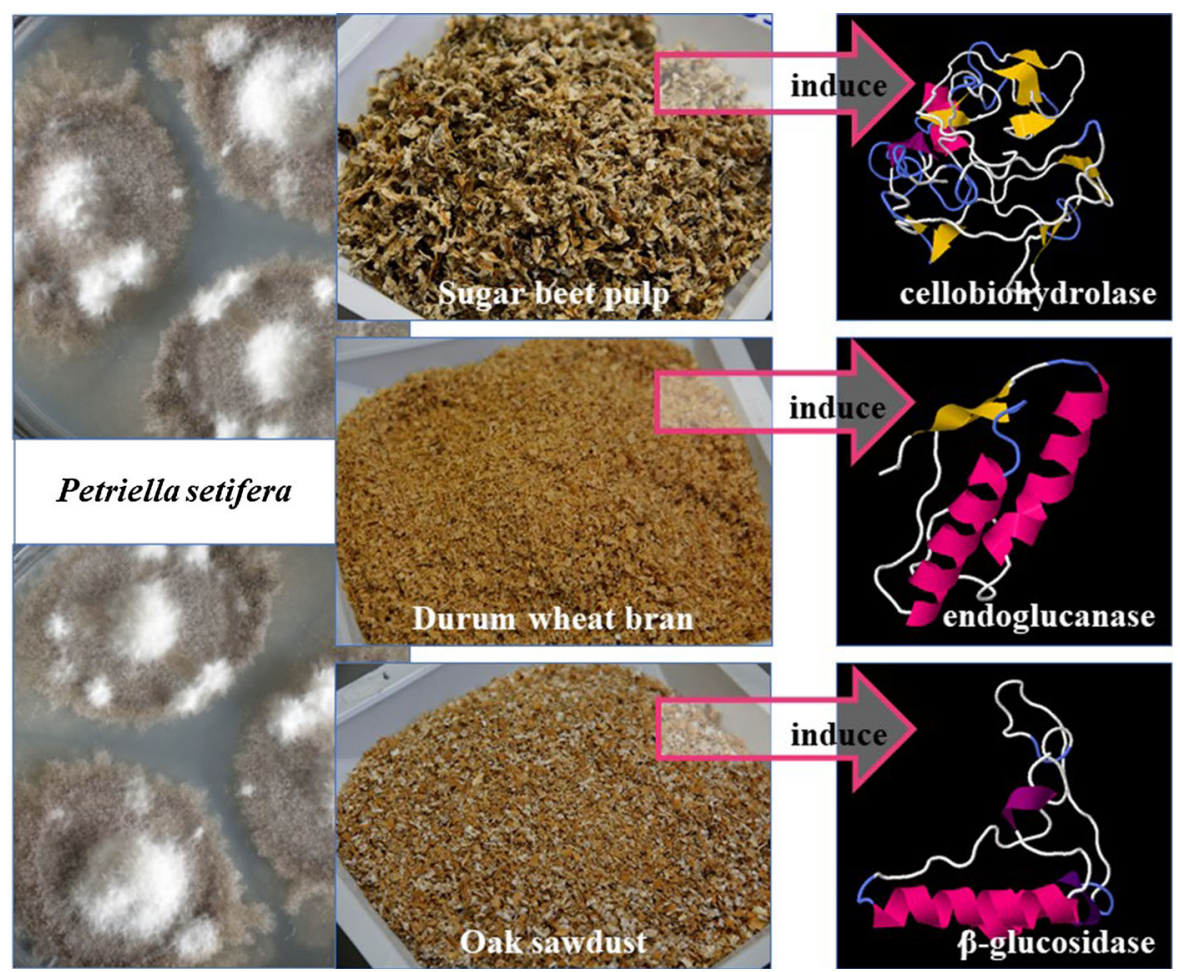

Keywords Cellulose degradation - Carbon catabolite repression $\cdot$ Petriella setifera $\cdot$ Biolog MT2 plate $\cdot$ Enzyme activities $\cdot$ Gene expression

\section{Introduction}

Filamentous fungi (FF) are heterotrophic eukaryotes and their growth and life depend on nutrient content and energy-rich feeds. The FF are saprophytes and they obtain nutrients from the degradation of a broad range of dead organic matter (More et al. 2010). Schlerotium rolfsii, Phanerochete chrysosporium, Trichoderma spp., Aspergillus spp., Schizophyllum spp., and Penicillium are FF and they use cellulolytic enzymes to degrade cellulose because they use it as a primary source of carbon, consequently involving in one of the main biochemical cycles: the carbon cycles. This typology of fungi is frequently used to analyse the expression of cellulolytic enzymes because of the higher production of these enzymes than bacteria and other fungi. Petriella setifera is a fungus belonging to the Microascaceae family (Ascomycota phylum). However, only fragmentary information concerning the functional characterization of this fungus is available. It is known that $P$. setifera inhabits enriched soil (e.g. dung, manure or compost) (Danon et al. 2010; Lackner and De Hoog 2011) and belongs to the group of soft rot fungi (Mathieu et al. 2013). This category of fungi can degrade both cellulose and hemicellulose, but it also has the ability to decompose lignin (Hammel 1997; Martínez et al. 2005). Cellulose degradation is less known in the Ascomycota phylum though it (especially FF) can degrade lignocellulosic material under inaccessible conditions for the Basidiomycota phylum (e.g. higher humidity, $\mathrm{pH}$ or temperature) (More et al. 2010). In our previous paper (Pertile et al. 2018), P. setifera was isolated from industrial compost and it was noted that this fungus can degrade the by-products from cellulose, hemicellulose, and lignin degradation. These findings highlight the importance of the function of the ecosystem services that this fungus provides. In particular, this is significant because cellulose degradation plays a key role in all important nutrient cycles, especially for the 
carbon cycle. The degradation of this important polymer relates to the hydrolysis of $\beta$-1,4-glycosidic bonds and this reaction is facilitated by the cellulase enzyme complex. This enzyme is mainly composed of cellobiohydrolase (EC 3.2.1.91), endoglucanase (EC 3.2.1.4) and $\beta$-glucosidase (EC 3.2.1.21). All of these enzymes belong to the Glycoside Hydrolase (GH; http://www.cazy.org/Glycoside-Hydrolases.html) family and they are grouped according to the structure of their catalytic domain into more than 70 families. Cellobiohydrolase $(\mathrm{CBH})$ cleaves cellobiose from the end of the cellulose chain and it belongs to the GH7 family. $\mathrm{CBH}$ is encoded by the $c b h$ gene. Endoglucanase (EGL) removes the amorphous region inside the cellulose chain creating an open site for the $\mathrm{CBH}$ enzyme; it belongs to the GH5 family. EGL is encoded by the egl gene. The last enzyme is $\beta$-glucosidase (BGL) and it has the function of degrading cellobiose to glucose. It belongs to the GH3 family and is encoded by the $b g l$ gene. These three enzymes work synergistically to degrade cellulose (Sánchez 2009; Teugjas and Väljamäe 2013). Cellulase production is influenced by several factors, in particular by the type of strain, culture conditions and the substrates being analysed (Niranjane et al. 2007) more precisely, by the type of carbon source present in the medium (Gao et al. 2008). The fungal cellulase enzyme is only produced when plant biomass is the only carbon source available to the fungus. In fact, the activities of the enzyme are repressed in the presence of easily metabolized carbon sources (e.g. glucose and cellobiose) and they are activated in the presence of substrate polymers (e.g. sophorose, gentiobiose, cellobiose, xylose and D-xylose) (Ilmén et al. 1997; Aro et al. 2005; Suzuki et al. 2008; Ahmed et al. 2009; Amore et al. 2013; Yamakawa et al. 2013; Raulo et al. 2016). In summary, cellulase production is affected by the induction and repression of glucose; whereas the by-product of cellulose degradation provides the induction of cellulase production $(\mathrm{Ju}$ and Afolabi 1999).

Petriella setifera has been classified as soft rot fungus, but Mathieu et al. (2013) has established that this fungus may be classified (through enzymatic analysis) as brown rot fungus. In our previous work (Oszust et al. 2018), this fungus pre-cultured was analysed on three different lignocellulolytic media and we found that the $P$. setifera strains decomposed the medium composed of protein, macroelements $(\mathrm{N}, \mathrm{P}$, and K) and easily accessible sugar rather than the medium which was rich in lignocellulose (i.e. sawdust). Together, the strains that were grown on the medium rich in lignocellulose presented changes at the level of their metabolic and genetic features. The adaptive response to the culture medium conditions of $P$. setifera could change the genetic expression of the fungus to produce a specific enzyme and isoforms (Tirado-González et al. 2016). This process depends on the fungal species and the sampling time (TiradoGonzález et al. 2016). Knowing a possible use of rich compost of lignocellulose in the agricultural field, the aim of the study was the evaluation of carbon sources utilization, enzyme activities and gene expression of the fungal strains pre-cultured in four different media; the control and three different wastes, with a different content of cellulose, hemicellulose, and lignin, i.e. oak sawdust (OS), dried sugar beet pulp (BP) and durum wheat bran (WB). The methodologies, described above, were used because the enzymatic activity and gene expression produce quantitative data of putative functional traits (Mathieu et al. 2013), whereas the Biolog MT2 plate analysis is an efficient and alternative methodology used to analyse microorganisms as they degrade the lignocellulosic substrate (Taha et al. 2015).

\section{Methods}

Petriella setifera strains and lignocellulosic material characterization

Five fungal strains of $P$. setifera (G11/16, G14/16, G16/16, G17/16, and G18/16) were selected from the fungal collection of the Laboratory of Molecular and Environmental Microbiology, Institute of Agrophysics, Polish Academy of Sciences (Lublin, Poland). All of the relevant information about the identification of the five strains was included in our previous publications (Oszust et al. 2018; Pertile et al. 2018). Three different lignocellulosic wastes were analysed: oak sawdust (OS), dried sugar beet pulp (BP) and durum wheat bran (WB). The three wastes were powdered using a ball mill (Retsch MM 400, $30 \mathrm{~Hz}$ ) for $15 \mathrm{~min}$. Chemical analyses were conducted as described by Oleszek and Krzemińska (2017). The total nitrogen content was analysed using the Kjeldahl method (Corporation 1998). 
Metabolic, enzymatic and functional analyses

To prepare an inoculum for MT2 plates evaluation, each isolate was cultivated on Potato Dextrose Agar medium (PDA; Oxoid Ltd, England) with 3\% (w/v) addition of oak sawdust, dried sugar beet pulp or durum wheat bran and control medium (PDA without the addition of waste), at $26{ }^{\circ} \mathrm{C}$ in the dark for 45 days in total, including 7 days with white light exposure for spore formation. The modified procedure of Frąc et al. (2016) was following: $100 \mu \mathrm{l}$ of mycelium suspension (75\% transmittance in FF inoculating fluid, Biolog ${ }^{\circledR}$ ) was added to each well, which was located on the MT2 plate, in four replicates, where previously $50 \mu \mathrm{l}$ of $1 \%$ of carbon sources were placed. The analysed carbon sources were as follows: carboxymethylcellulose $\left(\mathrm{CMC}\right.$; Fluka ${ }^{\circledR}$ Analytical, USA), cellobiose (CB; AppliChem, USA), microcrystalline cellulose (VP; Vivapur $^{\circledR}$ 101, JRS Pharma, Germany), powdered cellulose (AB; Arbocel $^{\circledR}$ M80, JRS Pharma, Germany) and crumbled Whatman No. 1 cellulose filter paper (FPU) obtained using a ball mill $(300 \mathrm{~Hz})$ for $20 \mathrm{~min}$. The inoculated microplates were incubated at $27{ }^{\circ} \mathrm{C}$ for 10 days. The optical density at $490 \mathrm{~nm}$ and $750 \mathrm{~nm}$ was determined every $24 \mathrm{~h}$ using a microplate reader until the 8th day of incubation.

Functional diversity was determined by the Average Well Density Development (AWDD) index and it was measured from the optical density of each well, corrected for the blank (water) and divided by the total number of the wells used. Furthermore, the metabolism analysis was analysed through the ratio of the substrate use (respiration, OD $490 \mathrm{~nm}$ ) and mycelium growing (OD $750 \mathrm{~nm}$ ). This ratio compares the metabolic activity and the biomass development (Pinzari et al. 2014, 2016).

The cellulolytic activity of $P$. setifera was determined calorimetrically in liquid culture filtrates during the incubation period (from 2 to 7 days). The culture conditions were as follows: $12 \mathrm{ml}$ Potato Dextrose Broth (PDB; Biocorp ${ }^{\circledR}$, Poland) with the addition of $1 \%$ microcrystalline cellulose (Vivapur ${ }^{\circledR}$ 101, Germany) in a $50 \mathrm{ml}$ Erlenmeyer flask, at $28{ }^{\circ} \mathrm{C}, 160 \mathrm{rpm}$ shaking, and $\sim 2 \times 10^{5}$ spores as an inoculum for each fungal strain (prepared as for the evaluation of MT2 plates). Each liquid media was centrifuged at $4000 \mathrm{rpm}$ for $20 \mathrm{~min}$. The supernatant was recovered to determine enzymatic activity and the pellet was stored at $-20{ }^{\circ} \mathrm{C}$ for RNA extraction. Cellulolytic activity determination included: total cellulase activity (FPase) evaluation after $60 \mathrm{~min}$ of incubation at $50{ }^{\circ} \mathrm{C}, \mathrm{pH} 4.5$ according to Mandels et al. (1976), King et al. (2009), and Oszust et al. (2017); carboxymethylcellulase (CMCase) determination following the Hankin and Anagnostakis (1977) protocol, after 30 min of incubation at $50{ }^{\circ} \mathrm{C}, \mathrm{pH} 4.5$; and $\beta$ glucosidase (BGL) determination, through the Deschamps and Huet (1984) protocol, after $15 \mathrm{~min}$ at $37{ }^{\circ} \mathrm{C}$. The analyses were performed in analytical triplicate for each of the biological duplicate experiments $(n=6)$. The enzyme unit used in our paper is one unit (U) and it quantifies the amount of enzyme required to release $1 \mu \mathrm{mol}$ of reducing sugar from the appropriate substrates per minute. FPase and CMCase

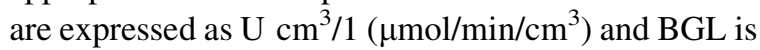
expressed as $\mathrm{nmol} / \mathrm{min} / \mathrm{cm}^{3}$.

The RNA was extracted using a MagMAX ${ }^{\mathrm{TM}}-96$ Total RNA Isolation Kit (ThermoFischer, USA) with a modified homogenization step (Oszust et al. 2018). $100 \mathrm{mg}$ of mycelium (previously stored at $-20^{\circ} \mathrm{C}$ ) was suspended in $1 \mathrm{ml}$ of nuclease-free water. Then the samples were vortexed for $3 \mathrm{~min}$ and $165 \mu \mathrm{l}$ of each suspension was transferred to BeadTubes (ThermoFischer, USA) containing $235 \mu \mathrm{l}$ of Lyse F buffer (EURx, Poland). The samples were homogenized by a FastPrep-24 instrument (MP Biomedicals, USA) at $6.5 \mathrm{~m} / \mathrm{s}$ with two cycles of $1 \mathrm{~min}$ each separated by 2 min intervals. After that, the samples were centrifuged at 16,000 rcf for $210 \mathrm{~s}$ and $200 \mu \mathrm{l}$ of each lysate was transferred to a new tube. To clarify the lysate, the samples were centrifuged at 16,000 rcf for 360 s. Reverse Transcription (RT) was performed using a High-Capacity cDNA Reverse Transcription Kit (ThermoFischer, USA), $10 \mu \mathrm{M}$ of anchored Oligo(dT)20 Primer and $10 \mu \mathrm{l}$ of RNA. The reaction mixture was incubated at $25{ }^{\circ} \mathrm{C}$ for $10 \mathrm{~min}, 37^{\circ} \mathrm{C}$ for $120 \mathrm{~min}$ and $85^{\circ} \mathrm{C}$ for $5 \mathrm{~min}$. Samples were stored at $-20^{\circ} \mathrm{C}$ until a qPCR analysis was performed.

The relative amount of $c b h$, egl, and $b g l$ gene transcripts were determined by qPCR for all four analysed samples, one control and 3 waste samples, after a range from 2 to 7 days of growth under the same conditions for enzymatic activity analyses. Before performing qPCR, the primers were tested (Table 1) on the DNA of the five analysed strains to be certain to obtain the correct PCR-product through sequencing by an ABI 3130 Genomic Analyzer (ThemoFisher, USA). 
Table 1 The primer used for sequencing and qPCR

\begin{tabular}{|c|c|c|c|c|c|c|}
\hline Gene & Primer & Nucleotide sequence $5^{\prime}$ to $3^{\prime}$ & $\begin{array}{l}\text { PCR } \\
\text { fragment } \\
\text { (bp) }\end{array}$ & $\begin{array}{l}\text { E value } \\
(\%)\end{array}$ & $\mathrm{R}^{2}$ value & References \\
\hline$c b h$ & $\begin{array}{l}\text { fungcbhl-F } \\
\text { fungcbhl-R }\end{array}$ & $\begin{array}{l}\text { ACC AAY TGC TAY ACI RGY AA } \\
\text { GCY TCC CAI ATR TCC ATC }\end{array}$ & 587 & 119.09 & 0.95 & $\begin{array}{l}\text { Edwards et al. (2008), } \\
\text { Weber et al. (2011), } \\
\text { Hannula et al. (2013), } \\
\text { Barbi et al. (2014) and } \\
\text { Yuan and Chen (2014) }\end{array}$ \\
\hline$e g l$ & $\begin{array}{l}\text { fungGH5-5-F } \\
\text { fungGH5-5-R }\end{array}$ & $\begin{array}{l}\text { GAR ATG CAY CAR TAC CTY GA } \\
\text { CA NGG ICC RGC RGC CCA CCA }\end{array}$ & 248 & 116.478 & 0.984 & Barbi et al. (2014) \\
\hline$b g l$ & $\begin{array}{l}\text { Glc1_155F } \\
\text { Glc1_235R }\end{array}$ & $\begin{array}{l}\text { GGI MGI AAY TGG GAR GGN TT } \\
\text { AY IGC RTC IGC RAA NGG CCA }\end{array}$ & 275 & 96.65 & 0.921 & $\begin{array}{l}\text { Kellner et al. (2010) and } \\
\text { Yuan and Chen (2014) }\end{array}$ \\
\hline efla & $\begin{array}{l}\text { Ps-EF1a_F } \\
\text { Ps-EF1a_R }\end{array}$ & $\begin{array}{l}\text { CGA GAC CGG TAT CMT CAA GC } \\
\text { AAR CCR ACG TTG TCA CCG GG }\end{array}$ & 128 & 119.09 & 0.997 & This study (see Fig. S2) \\
\hline
\end{tabular}

All of the sequences of the three functional genes for all five strains were deposited in the NCBI (http:// www.ncbi.nlm.nih.gov) (Woodsmall and Benson 1993) and are as follows: for the $c b h$ gene- MF673402, MF673405, MF673407, MF673408 and MF673409; for the egl gene- MF673397, MF673398, MF673399, MF673400 and MF673401; and for the $b g l$ geneMF684777, MF684778, MF684779, MF684780 and MF684781. Furthermore, a model for each enzyme was constructed using the SWISS-MODEL (Biozentrum, Switzerland) (Arnold et al. 2006; Guex et al. 2009; Kiefer et al. 2009; Biasini et al. 2014) and JMOL software (Fig. S1).

The qPCR reactions were conducted with two biological replicates for each cDNA sample. For each qPCR, a negative control was run plus an RNA positive control to determine whether the reverse transcription and/or qPCR reaction and conditions were optimal. The qPCR reactions were performed in a final volume of $10 \mu \mathrm{l}$; the reaction mixture was composed of 1X SG qPCR Master Mix (EURx, Poland), $0.4 \mu \mathrm{M}$ of each primer (Genomed, Poland), $30 \mathrm{nM}$ ROX and $3 \mu \mathrm{l}$ of cDNA. The reaction was performed in a 7500 Fast Real-Time PCR System (Applied Biosystems, USA) under the following conditions: $95{ }^{\circ} \mathrm{C}$ for $5 \mathrm{~min}$ followed by 40 cycles at $95{ }^{\circ} \mathrm{C}$ for $15 \mathrm{~s}, 50{ }^{\circ} \mathrm{C}$ for $45 \mathrm{~s}$ and $76{ }^{\circ} \mathrm{C}$ for $1 \mathrm{~min}$. The melting curve analysis was performed at $95{ }^{\circ} \mathrm{C}$ for $15 \mathrm{~s}, 60^{\circ} \mathrm{C}$ for $1 \mathrm{~min}, 95^{\circ} \mathrm{C}$ for $30 \mathrm{~s}$ and $60^{\circ} \mathrm{C}$ for $15 \mathrm{~s}$. Fluorescence was measured during each elongation step.
To normalize the relative quantification of the cDNA, the elongation factor-1 alfa gene (efla) was used as an internal control. This gene was used because in the NCBI database there are only three housekeeping genes [efla, $\beta$-tubulin ( $\beta$-tub) and RNA polymerase II beta subunit (RPB2)] published for this fungus. A primers specific for these three genes was selected and only the PCR-product that was obtained from the efla presented a good similarity with the sequences published in the database (see Fig. S1 and $\mathrm{S} 2$ and Table S1). The relative expression of the cellulose-acting gene was calculated using the Pfaffl equation (Pfaffl 2004) ratio $=(\mathrm{E} \text { target })^{\Delta \mathrm{CP}(\text { control-sample })} /$

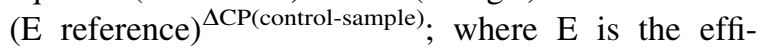
ciency of the qPCR and the $\triangle \mathrm{CP}$ is a comparison of the threshold values $(\mathrm{Ct})$ of the control and sample. The results are reported as relative fold change.

\section{Statistical analysis}

To illustrate the Biolog results, the similarity between the strains of five different types of carbon was presented by means of a heatmap graph. For the AWDD index, enzymatic activities and relative quantification were assessed, using a two-way ANOVA analysis including the effect of the incubation hours, the strains, and the different analysed substrates. Successively, the significant differences were calculated by a post hoc analysis using the Tukey test.

Moreover, Pearson's correlation between the chemical characteristics of the three tested wastes and the 
molecular and biochemical analyses were made. All of the statistical analyses, which are described above, were performed with the use of STATISTICA 12.0 software (StatSoft, Inc., USA).

\section{Results}

Chemical characteristic of the waste

The chemical characteristics of each analysed waste are presented in Table 2.

The waste that contained most lignocellulosic materials was oak sawdust (OS). This waste contained $93.91 \%$ total solids, of which $84.10 \%$ is lignocellulosic $(27.20 \%$ hemicellulose, $42.90 \%$ cellulose, and $14 \%$ lignin). The two remaining wastes had a lower content of lignocellulosic materials. The dried sugar beet pulp (BP) was composed of $92.49 \%$ total solids, of which $57.10 \%$ was lignocellulosic (37\% hemicellulose, $17.5 \%$ cellulose, and $2.60 \%$ lignin), whereas the durum wheat bran (WB) consisted of $91.52 \%$ total solids, of which $41 \%$ was lignocellulosic $(31.30 \%$ hemicellulose, $7.7 \%$ cellulose, and $2 \%$ lignin). WB waste had a high content of crude fat (CF), crude protein $(\mathrm{CP})$, total nitrogen $\left(\mathrm{N}_{\text {total }}\right)$, and non-fibre carbohydrates (NFC); but most importantly this waste had a lower quantity of cellulose (CEL), lignin (ADL), and acid detergent fibre (ADF). OS was characterized by a higher concentration of CEL, neutral detergent fibre (NDF), ADF, and ADL and by a lower content of $\mathrm{N}_{\text {total }}$, crude ash (CA), NFC and CP. For the last waste (BP) to be analysed, a higher content of hemicellulose (HCEL), and CA were detected whereas the contents of lignin and $\mathrm{CF}$ were determined to be at a lower level. Our findings were in accordance with other studies (Mikiashvili et al. 2011; Stevenson et al. 2012).

\section{Metabolic activity}

Through our analysis of four wastes, the differences and the resulting significant behaviours from using five different carbon sources on the strains grown on different wastes were observed (Fig. 1).

The durum wheat bran (WB) wastes produced a high AWDD index, whereas the dried sugar beet pulp (BP) and the oak sawdust (OS) had a lower AWDD index.
These different behaviours became more evident when the AWDD index was analysed as a function of added carbon sources (Fig. 2). The findings clearly showed that $P$. setifera utilized more cellobiose (CB) from the CTRL, WB and OS wastes, whereas all wastes did not influence the utilization of powdered cellulose $(\mathrm{AB})$. Carboxymethylcellulose (CMC) and microcrystalline cellulose (VP) showed that a high level of activity occurred in the CTRL medium and a lower one in the BP waste. On the other hand, the filter paper unit (FPU) was more completely metabolized by the fungus that grew in the pre-cultured conditions of all analysed wastes and less in the CTRL medium.

The ratio 490/750 $\mathrm{nm}$ (Table 3) had provided us that the G16/16 and G18/16 strains had a higher ratio because the respiration rate was higher than the biomass development. Whereas, the strain G11/16, cultivated on the three different waste, presented a best efficiency in all substrates than the control. The observation of this ratio, in function of each strain, showed that all analysed strains (with exception of the strain G11/16 cultivated on dried sugar beet pulp) presented a best efficiency on CMC substrate. Analysing the correlation between the chemical characterizations of the three tested wastes and the utilization of the different carbon sources (Table 4), it was observed that the crude fat (CF) was positively correlated with the degradation of CMC (0.998; $p$ value $<0.05$ ).

\section{Enzymatic activity}

The total cellulase (FPase), carboxymethylcellulase (CMCase) and $\beta$-glucosidase (BGL) enzyme activities are expressed for all wastes as $0.0037 \mathrm{U} / \mathrm{cm}^{3}$, $0.0841 \mathrm{U} / \mathrm{cm}^{3}$ and $8.0923 \mathrm{nmol} / \mathrm{min} / \mathrm{cm}^{3}$, respectively. The averages of the standardized enzymatic activities were higher for the durum wheat bran (WB) and oak sawdust (OS) than for the control (PDB medium; CTRL) (Fig. 3).

When each enzymatic activity was analysed separately, a different behaviour for each strain as a function of the growth substrate was observed. The only enzymatic activity that showed no statistically significant difference was FPase (Fig. S3). The CMCase activities in all tested wastes were higher compared to the control (Fig. 4) and, in particular, it had a higher level of activity of ca. $0.14 \mathrm{U} / \mathrm{cm}^{3}$ in OS and $0.12 \mathrm{U} / \mathrm{cm}^{3}$ in dried sugar beet pulp (BP) wastes 
Table 2 Chemical characterizations of analysed wastes

\begin{tabular}{|c|c|c|c|}
\hline Characteristics & Durum wheat bran (WB) & Oak sawdust (OS) & Dried sugar beet pulp (BP) \\
\hline $\mathrm{TS}[\%]$ & $91.52 \pm 0.12$ & $93.91 \pm 0.13$ & $92.49 \pm 0.07$ \\
\hline $\mathrm{VS}[\% \mathrm{TS}]$ & $96.21 \pm 0.11$ & $99.24 \pm 0.05$ & $96.00 \pm 0.08$ \\
\hline CA $[\%$ TS $]$ & $3.79 \pm 0.11$ & $0.76 \pm 0.05$ & $4.00 \pm 0.08$ \\
\hline $\mathrm{N}_{\text {total }}[\% \mathrm{TS}]$ & $2.94 \pm 0.11$ & $0.16 \pm 0.02$ & $1.51 \pm 0.03$ \\
\hline $\mathrm{CP}[\% \mathrm{TS}]$ & $18.40 \pm 0.70$ & $1.00 \pm 0.1$ & $9.40 \pm 0.20$ \\
\hline $\mathrm{CF}[\% \mathrm{TS}]$ & $4.39 \pm 0.46$ & $0.95 \pm 0.05$ & $0.35 \pm 0.00$ \\
\hline $\mathrm{NFC}\left[\begin{array}{ll}\% & \mathrm{TS}\end{array}\right]^{\mathrm{a}}$ & $32.46 \pm 1.02$ & $13.22 \pm 1.02$ & $29.11 \pm 1.10$ \\
\hline $\mathrm{NDF}[\% \mathrm{TS}]$ & $41.00 \pm 1.30$ & $84.10 \pm 1.00$ & $57.10 \pm 1.20$ \\
\hline $\mathrm{ADF}[\% \mathrm{TS}]$ & $9.70 \pm 0.50$ & $56.80 \pm 1.40$ & $20.20 \pm 0.90$ \\
\hline $\mathrm{ADL}[\% \mathrm{TS}]$ & $2.00 \pm 0.30$ & $14.00 \pm 0.50$ & $2.60 \pm 0.10$ \\
\hline CEL $[\%$ TS $]$ & $7.70 \pm 0.30$ & $42.90 \pm 0.90$ & $17.50 \pm 1.00$ \\
\hline HCEL [\% TS] & $31.30 \pm 1.00$ & $27.20 \pm 0.60$ & $37.00 \pm 0.60$ \\
\hline CEL/LIG & 19.5 & 5.01 & 20.96 \\
\hline LIG/HCEL & 0.06 & 0.51 & 0.07 \\
\hline
\end{tabular}

Data are expressed as the mean \pm standard deviation of three replicates samples

${ }^{\mathrm{a}} \mathrm{NFC}=100 \%-(\mathrm{CP}+\mathrm{CF}+\mathrm{NDF}+\mathrm{CA})$

TS Total solids, VS Volatile solids, $C A$ Crude ash, $N_{\text {total }}$ Total nitrogen, $C P$ Crude protein, $C F$ Crude fat, NFC Non-fibre carbohydrates, $N D F$ Neutral detergent fibre, $A D F$ Acid detergent fibre, $A D L$ Acid detergent lignin, $C E L$ Cellulose, $H C E L$ Hemicellulose, $C E L / L I G$ ratio between cellulose and lignin content, $L I G / H C E L$ ratio between lignin and hemicellulose content

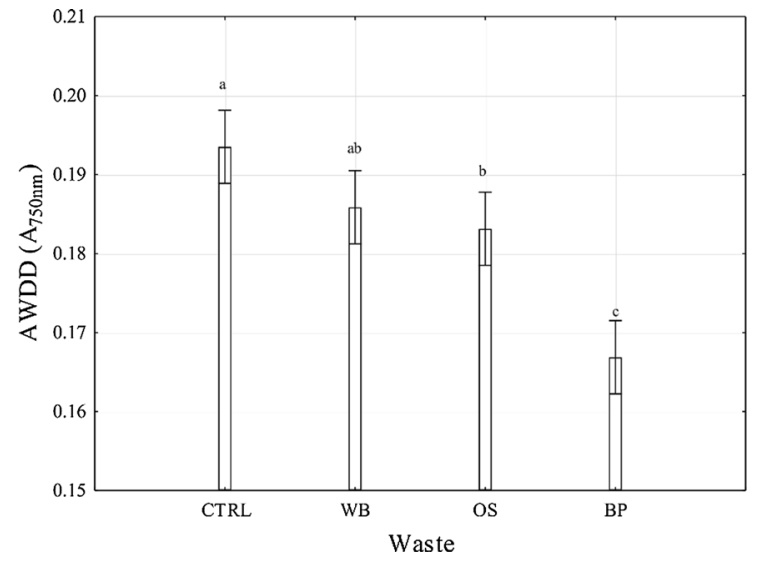

Fig. 1 Average Well Density Development (AWDD) index of metabolized carbon substrates. Vertical bars represent confidence intervals at 0.95 . The lower-case letters above each column describe the statistical difference between the treatments (calculated by Tukey test; see Table S2). CTRL Control, $W B$ Durum wheat bran, $O S$ Durum wheat bran, $B P$ Dried sugar beet pulp

than in the CTRL and WB substrates (approximately, they were just under 10-fold; Fig. 4a).

Analysing the value of the enzymatic activity during the incubation period, the CTRL medium

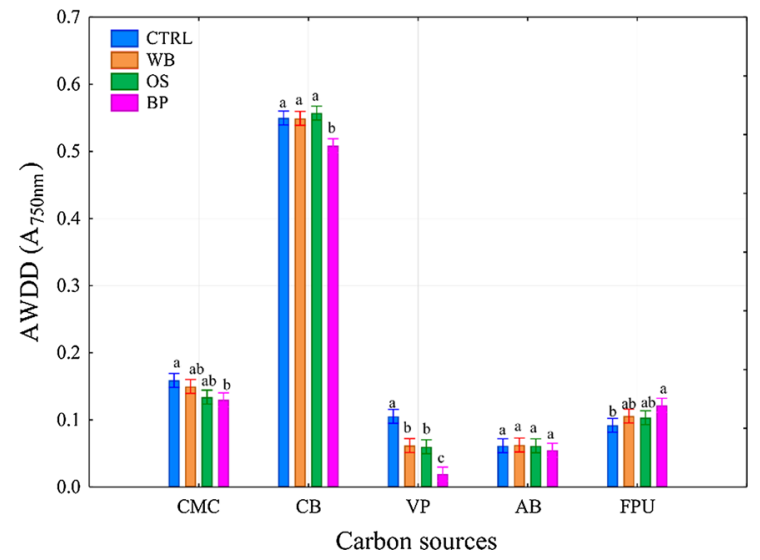

Fig. 2 Average Well Density Development (AWDD) index in function of the waste and carbon sources. Vertical bars represent confidence interval at 0.95 . The lower-case letters above each column describe the statistical difference between the treatments (calculated by Tukey test; see Table S2). CMC carboxymethylcellulose, $C B$ Cellobiose, $V P$ Microcrystalline cellulose, $A B$ Powdered cellulose, FPU Filter paper unit, $C T R L$ Control, WB Durum wheat bran, $O S$ Oak sawdust, $B P$ Dried sugar beet pulp

presented a very low CMCase activity for the whole incubation period which was close to $0 \mathrm{U} / \mathrm{cm}^{3}$ (Fig. 4b). 
Table 3 Ratio 490/750 nm of the single strains and analysed wastes in function of the different carbon sources

\begin{tabular}{|c|c|c|c|c|c|c|c|c|c|c|c|c|c|c|c|c|c|c|c|c|}
\hline & \multicolumn{4}{|c|}{ G11/16 } & \multicolumn{4}{|c|}{ G14/16 } & \multicolumn{4}{|c|}{ G16/16 } & \multicolumn{4}{|c|}{ G17/16 } & \multicolumn{4}{|c|}{ G18/16 } \\
\hline & OS & BP & WB & CTRL & OS & BP & WB & CTRL & OS & BP & WB & CTRL & OS & BP & WB & CTRL & OS & BP & WB & CTRL \\
\hline CMC & 1.258 & 1.370 & 1.207 & 1.383 & 1.610 & 1.324 & 1.271 & 1.322 & 1.732 & 1.555 & 1.633 & 1.521 & 1.472 & 1.418 & 1.378 & 1.349 & 1.403 & 1.492 & 1.378 & 1.319 \\
\hline CB & 2.224 & 2.026 & 1.674 & 1.482 & 2.449 & 2.216 & 1.942 & 1.808 & 2.341 & 2.084 & 1.952 & 2.052 & 2.119 & 2.084 & 1.949 & 1.514 & 2.118 & 1.816 & 1.783 & 1.839 \\
\hline VP & 3.342 & 0.210 & 1.825 & -1.215 & 2.563 & 2.317 & 1.886 & 2.474 & 3.903 & 6.244 & -4.736 & 2.688 & 2.761 & 1.937 & 1.900 & 1.482 & 3.035 & -3.904 & -53.800 & 2.315 \\
\hline $\mathbf{A B}$ & 2.546 & 2.256 & 3.548 & 3.386 & 4.668 & 3.473 & 2.489 & 3.025 & 4.145 & 5.140 & 5.291 & 3.371 & 270.667 & 3.074 & 2.491 & 3.311 & 3.237 & 3.727 & 9.189 & 3.215 \\
\hline FPU & 1.535 & 1.792 & 2.033 & 1.879 & 1.832 & 1.846 & 1.782 & 2.280 & 3.268 & 2.171 & 2.837 & 2.286 & 1.891 & 1.863 & 1.743 & 3.390 & 2.058 & 2.061 & 2.454 & 2.006 \\
\hline
\end{tabular}

$O S$ Oak sawdust, $B P$ dried sugar beet pulp, $W B$ durum wheat bran, $C M C$ carboxymethylcellulose, $C B$ cellobiose, $V P$ microcrystalline cellulose, $A B$ powdered cellulose, $F P U$ cellulose filter paper. Highlight means the lower ratio inside each analysed carbon substrate (red colour) and the lower ration inside each analysed strain (yellow colour). More the ratio is lower, more the metabolism is efficient. This means that the activity of the mycelium growing is higher than the metabolic activity

The same trend was observed for WB waste at the beginning of the experiment and CMCase activity started to increase after 3 days of incubation to steady state of ca. $0.1 \mathrm{U} / \mathrm{cm}^{3}$ until the end of the experiment. BGL activity was higher for WB waste (ca. $20 \mathrm{nmol} /$ $\mathrm{min} / \mathrm{cm}^{3}$ ), whereas OS and BP produced a lower activity than the WB and the CTRL substrates (ca. 2-4 nmol $/ \mathrm{min} / \mathrm{cm}^{3}$; Fig. 5a). On the other hand, when we analysed BGL activity during the incubation time, we observed that WB waste had a higher activity (the maximum was reached with ca. $25 \mathrm{nmol} / \mathrm{min} / \mathrm{cm}^{3}$ on the 5th day of the experiment) than the other wastes and, in particular, the CTRL medium had a low activity until the 4th day and then it increased until the end of the incubation time (Fig. 5b).

Gene expression analyses

The relative quantification showed that only the $e g l$ and $b g l$ genes were expressed, especially in almost all of the analysed wastes and that the level of the $b g l$ gene was higher than the $e g l$ gene. The expression of the genes started at the 3rd day from the beginning of the incubation period (Fig. 6a). The trend of egl expression reached its height on the 3rd day and after that, it decreased to zerofold and remained stable until the end of the experiment. For the $b g l$ gene, the trend was not stable; in fact, it produced two high peaks (about 400-500-fold) on the 4th and 6th days. Also, when we analysed the expression of both genes according to the four wastes (Fig. 6b), the expression results had a statistical significance, and we observed that $b g l$ expression was higher for durum wheat bran (WB) and dried sugar beet pulp (BP) than it was found for the other wastes and for egl expression the highest value was produced by oak sawdust (OS).

Analysing the correlation between gene expression and the chemical characterization of the wastes, we found that the expression of the $e g l$ gene was positively correlated with volatile solids and negatively with crude ash and the ratio of cellulose to lignin content (Table 2). On the other hand, we found that the expression of the $b g l$ gene was negatively correlated with neutral detergent fibre and cellulose content (Table 2).

\section{Discussion}

In our previous work (Oszust et al. 2018), we found that the ratio of cellulose to lignin content was higher for the dried sugar beet pulp (42.43) and durum wheat bran (21.96), whereas for oak sawdust it was lower (4.95). This ratio provides important information concerning the affinity of the substrate to be degraded. In fact, these values explain why dried sugar beet pulp (BP) and durum wheat bran (WB) are susceptible to more advanced degradation by microorganisms than oak sawdust (OS). From our chemical analysis, we observed that the OS substrate does not present chemical characteristics that result in the stimulation of the production of the cellulase enzyme. Between the 
Table 4 Correlation coefficient between the chemical characterization of wastes and biochemical and biological analyses

\begin{tabular}{|c|c|c|c|c|c|c|c|c|c|c|}
\hline & \multicolumn{10}{|c|}{ Biolog analysis } \\
\hline & \multicolumn{2}{|l|}{$\mathrm{CMC}$} & \multicolumn{2}{|l|}{$\mathrm{CB}$} & \multicolumn{2}{|l|}{ VP } & \multicolumn{2}{|l|}{$\mathrm{AB}$} & \multicolumn{2}{|l|}{ FPU } \\
\hline & Corr. & $p$ value & Corr. & $p$ value & Corr. & $p$ value & Corr. & $p$ value & Corr. & $p$ value \\
\hline $\mathrm{TS}$ & -0.678 & 0.525 & 0.258 & 0.834 & 0.0071 & 0.955 & -0.048 & 0.969 & -0.234 & 0.850 \\
\hline VS & -0.269 & 0.827 & 0.670 & 0.532 & 0.518 & 0.653 & 0.412 & 0.729 & -0.651 & 0.549 \\
\hline $\mathrm{CA}$ & 0.269 & 0.827 & -0.670 & 0.532 & -0.518 & 0.653 & -0.412 & 0.729 & 0.651 & 0.549 \\
\hline $\mathrm{N}_{\text {total }}$ & 0.765 & 0.446 & -0.136 & 0.913 & 0.054 & 0.966 & 0.172 & 0.890 & 0.111 & 0.929 \\
\hline $\mathrm{CP}$ & 0.767 & 0.444 & -0.133 & 0.915 & 0.057 & 0.964 & 0.176 & 0.888 & 0.107 & 0.931 \\
\hline $\mathrm{CF}$ & 0.998 & 0.035 & 0.487 & 0.676 & 0.643 & 0.555 & 0.730 & 0.479 & -0.509 & 0.660 \\
\hline NFC & 0.474 & 0.686 & -0.491 & 0.674 & -0.317 & 0.795 & -0.202 & 0.871 & 0.468 & 0.690 \\
\hline NDF & -0.651 & 0.549 & 0.239 & 0.810 & 0.108 & 0.931 & -0.012 & 0.993 & -0.269 & 0.826 \\
\hline $\mathrm{ADF}$ & -0.518 & 0.654 & 0.446 & 0.706 & 0.269 & 0.827 & 0.153 & 0.903 & -0.423 & 0.722 \\
\hline ADL & -0.366 & 0.761 & 0.591 & 0.598 & 0.428 & 0.719 & 0.317 & 0.795 & -0.570 & 0.614 \\
\hline CEL & -0.567 & 0.616 & 0.392 & 0.743 & 0.212 & 0.864 & 0.094 & 0.940 & -0.369 & 0.759 \\
\hline HCEL & -0.283 & 0.817 & -0.962 & 0.176 & -0.893 & 0.297 & -0.833 & 0.373 & 0.955 & 0.192 \\
\hline CEL/LIG & 0.245 & 0.843 & -0.688 & 0.517 & -0.539 & 0.638 & -0.435 & 0.714 & 0.670 & 0.533 \\
\hline \multirow[t]{4}{*}{ LIG/HCEL } & -0.336 & 0.782 & 0.616 & 0.577 & 0.457 & 0.698 & 0.347 & 0.774 & -0.596 & 0.593 \\
\hline & \multicolumn{6}{|c|}{ Enzymatic activity } & \multicolumn{4}{|c|}{ Gene expression } \\
\hline & \multicolumn{2}{|l|}{ FPase } & \multicolumn{2}{|l|}{ CMCase } & \multicolumn{2}{|l|}{ BGL } & \multicolumn{2}{|l|}{$e g l$} & \multicolumn{2}{|l|}{$b g l$} \\
\hline & Corr. & $p$ value & Corr. & $p$ value & Corr. & $p$ value & Corr. & $p$ value & Corr. & $p$ value \\
\hline TS & 0.233 & 0.850 & 0.926 & 0.246 & -0.806 & 0.403 & 0.869 & 0.329 & -0.996 & 0.059 \\
\hline VS & 0.651 & 0.549 & 0.652 & 0.548 & -0.448 & 0.704 & 0.999 & 0.028 & -0.929 & 0.242 \\
\hline $\mathrm{CA}$ & -0.651 & 0.549 & -0.652 & 0.548 & 0.448 & 0.704 & -0.999 & 0.028 & 0.929 & 0.242 \\
\hline $\mathrm{N}_{\text {total }}$ & -0.110 & 0.930 & -0.966 & 0.167 & 0.874 & 0.323 & -0.801 & 0.409 & 0.976 & 0.139 \\
\hline $\mathrm{CP}$ & -0.107 & 0.932 & -0.967 & 0.165 & 0.875 & 0.321 & -0.799 & 0.411 & 0.976 & 0.141 \\
\hline $\mathrm{CF}$ & 0.510 & 0.660 & -0.928 & 0.244 & 0.991 & 0.087 & -0.280 & 0.819 & 0.650 & 0.549 \\
\hline NFC & -0.468 & 0.690 & -0.802 & 0.407 & 0.634 & 0.563 & -0.965 & 0.169 & 0.987 & 0.101 \\
\hline $\mathrm{NDF}$ & 0.269 & 0.827 & 0.912 & 0.270 & -0.784 & 0.426 & 0.887 & 0.306 & -0.998 & 0.036 \\
\hline $\mathrm{ADF}$ & 0.423 & 0.722 & 0.831 & 0.375 & -0.671 & 0.531 & 0.951 & 0.201 & -0.994 & 0.069 \\
\hline ADL & 0.570 & 0.614 & 0.726 & 0.483 & -0.537 & 0.639 & 0.989 & 0.093 & -0.962 & 0.177 \\
\hline CEL & 0.369 & 0.760 & 0.863 & 0.337 & -0.714 & 0.493 & 0.931 & 0.239 & -0.999 & 0.031 \\
\hline HCEL & -0.955 & 0.193 & -0.150 & 0.904 & -0.095 & 0.940 & -0.870 & 0.328 & 0.590 & 0.598 \\
\hline CEL/LIG & -0.669 & 0.533 & -0.633 & 0.564 & 0.426 & 0.720 & -1.000 & 0.012 & 0.919 & 0.258 \\
\hline LIG/HCEL & 0.596 & 0.594 & 0.704 & 0.503 & -0.510 & 0.659 & 0.994 & 0.073 & -0.952 & 0.197 \\
\hline
\end{tabular}

Pearson correlation coefficient was made between the chemical characterizations of the waste and the AWDD index, enzymatic activities, and gene expression. The bolded values indicate significant correlation coefficient with $p<0.05$

$T S$ Total solids, VS Volatile solids, $C A$ Crude ash, $N_{\text {total }}$ Total nitrogen, $C P$ Crude protein, $C F$ Crude fat, $N F C$ Non-fibre carbohydrates, $N D F$ Neutral detergent fibre, $A D F$ Acid detergent fibre, $A D L$ Acid detergent lignin, $C E L$ Cellulose, $H C E L$ Hemicellulose, CEL/LIG ratio between cellulose and lignin content, LIG/HCEL ratio between lignin and hemicellulose content

analysed wastes, WB stimulates and improves cellulase secretion. Wheat bran is a good source of nitrogen (because of the protein content) and hemicellulose (because of the soluble sugars content) (Duff and Murrayh 1996; Camassola and Dillon 2007; Brijwani et al. 2010). Soluble sugars or cello-oligosaccharides 


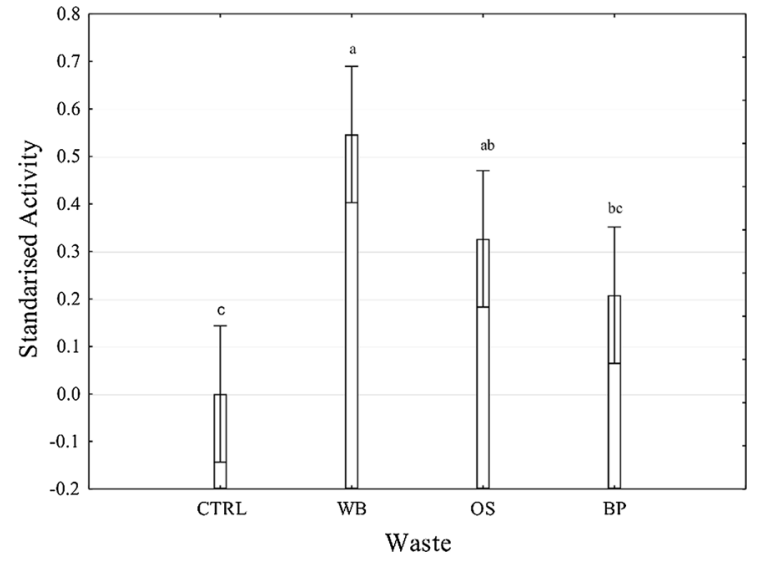

Fig. 3 Profile of standardizing enzymatic activities in each analysed waste. Vertical bars represent confidence intervals at 0.95 . The lower-case letters above each column describe the statistical difference between the treatments (calculated by Tukey test; see Table S3). CTRL Control, WB Durum wheat bran, $O S$ Oak sawdust, $B P$ Dried sugar beet pulp

(i.e. arabinose, xylose, cellobiose, and glucose) are needed for initial microbial growth, whereas cellulose and hemicellulose are used to stimulate cellulase production after the consumption of soluble sugars (Brijwani et al. 2010; Oberoi et al. 2010). Sun et al. (2008) reported that the composition of wheat bran is crude protein $(\sim 18 \%)$, starch $(\sim 19 \%)$, and nostarch carbohydrates $(\sim 58 \%$, of which $\sim 70 \%$ is arabinoxylans and $24 \%$ is cellulose). In particular, the last component described above plays two important roles: firstly it regulates the synthesis of enzymes

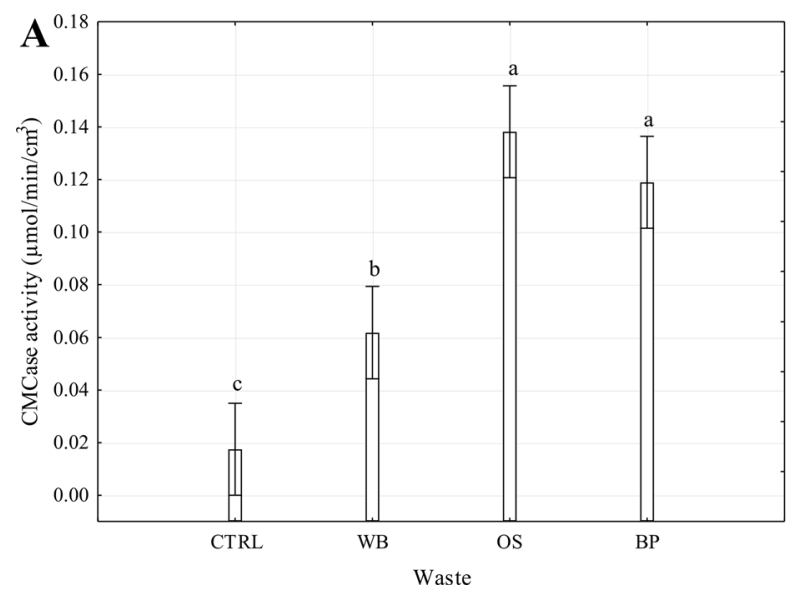

Fig. 4 Carboxymethylcellulase (CMCase) activity towards $\mathbf{a}$ analysed four wastes and $\mathbf{b}$ time course of enzyme production inside the four different analysed wastes. Vertical bars represent confidence intervals at 0.95 . The lower-case letters above each which participate in wood degradation by inducers (such as sophorose and gentiobiose) for enzymes production and secondly the presence of cellooligosaccharides can increase the cell synthesis of the filamentous fungi (FF) (Sun et al. 2008). In addition, the lower water content inside the WB solidculture can reduce the diffusion of free-glucose inside the medium (Maeda et al. 2004).

The Biolog analysis revealed another aspect of the utilization of different carbon sources after the fungus was pre-cultured on three different wastes. The first aspect was that the AWDD index (Fig. 1) for the control substrate (CTRL; in PDA medium) was higher than the waste samples analysed. However, the lowest AWDD index was noted for dried sugar beet pulp (BP) waste. The high value was related to the presence of glucose sources in the CTRL substrate (the stock of PDA medium contains $20 \mathrm{~g} / \mathrm{l}$ of dextrose) because this carbon supplier stimulates and increases the growth of the fungus and it is easy to use the carbon source, whereas the lower value could be related to the concentration of hemicellulose (correlation between the degradation of five carbon sources and the chemical characteristics was observed but the p-value was higher than 0.05; Table 4). All the strains grew more rapidly within the cellobiose $(\mathrm{CB})$ source because, from a biological/physiological point of view, the microorganisms use the most energetically favourable carbon sources available to conserve energy (in our case CB; Fig. 2). Fig 2 supports the

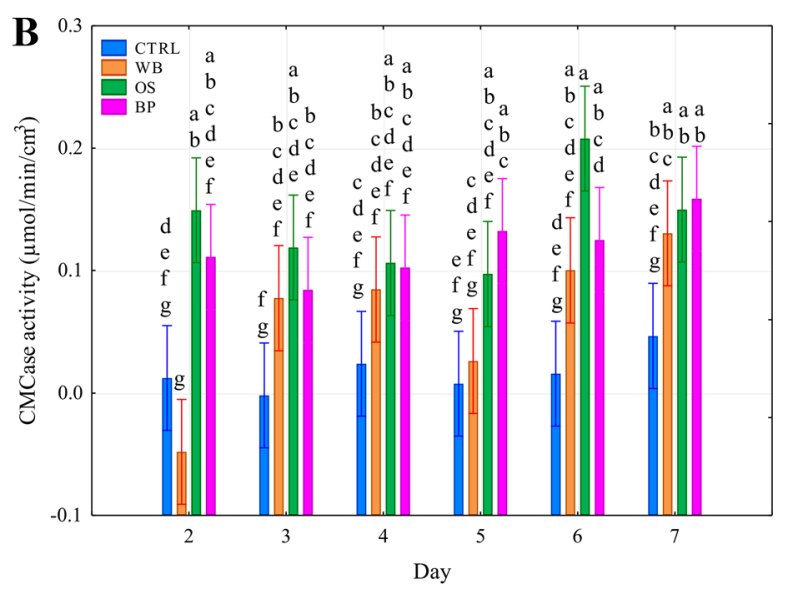

column describe the statistical difference between the treatments (calculated by Tukey test; see Table S4). CTRL Control, $W B$ Durum wheat bran, $O S$ Oak sawdust, $B P$ Dried sugar beet pulp 


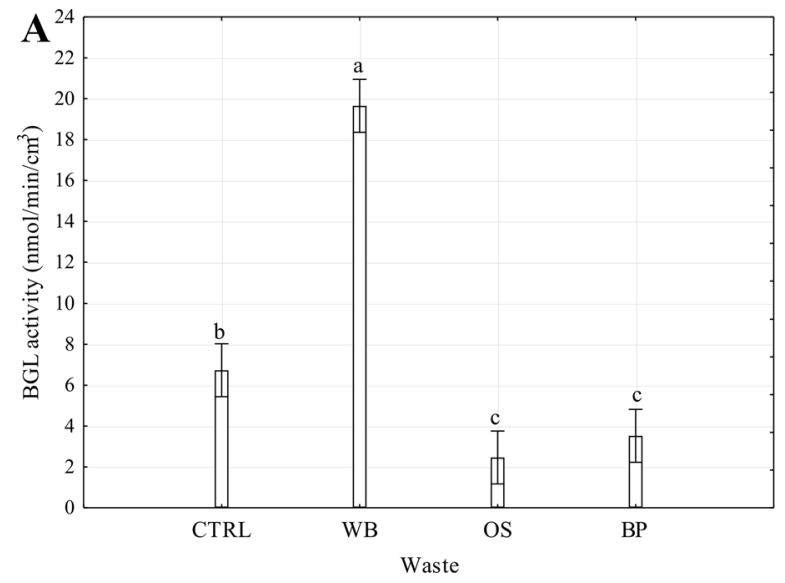

Fig. $5 \beta$-glucosidase (BGL) activity towards a analysed four wastes and $\mathbf{b}$ time course of enzyme production inside the four different analysed wastes. Vertical bars represent confidence intervals at 0.95 . The lower-case letters above each column

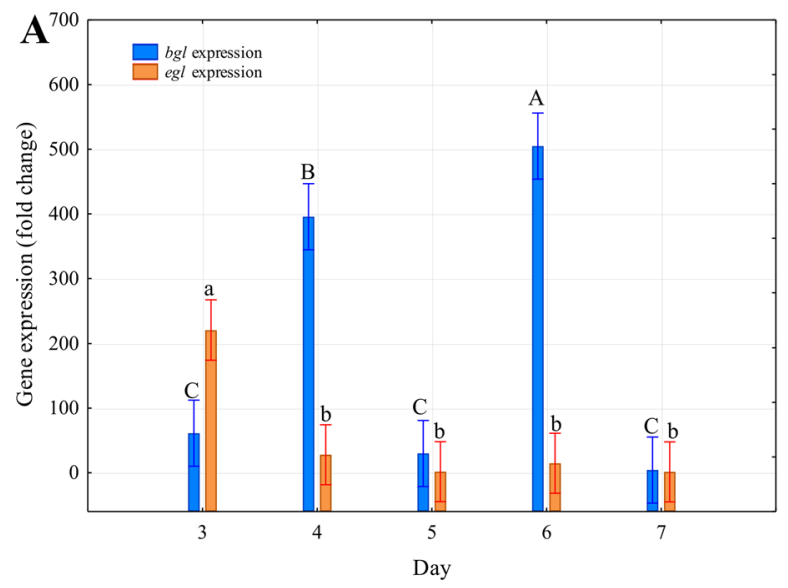

Fig. 6 Gene expression profiling of $e g l$ and $b g l$ genes in $P$. setifera. a Distribution of both genes towards incubation time (day) and b analysed four wastes. Vertical bars represent confidence intervals at 0.95 . The lower-case letters above each

possible correlation between the degradation of $\mathrm{CB}$ and hemicellulose (HEL) content inside the wastes because the utilization of this carbon source was high in the CTRL, durum wheat bran (WB), and oak sawdust (OS) and besides, these wastes had a lower HEL content than BP. In conclusion, the Biolog's results inform us that all the strains (unaffected by the form of cultured waste) grew very well in CB substrate (Fig. 2). These findings are related to the presence of cellobiose, which is connected with other study (Ilmén et al. 1997; Suzuki et al. 2008; Amore et al. 2013; Yamakawa et al. 2013) indicating that the cellobiose

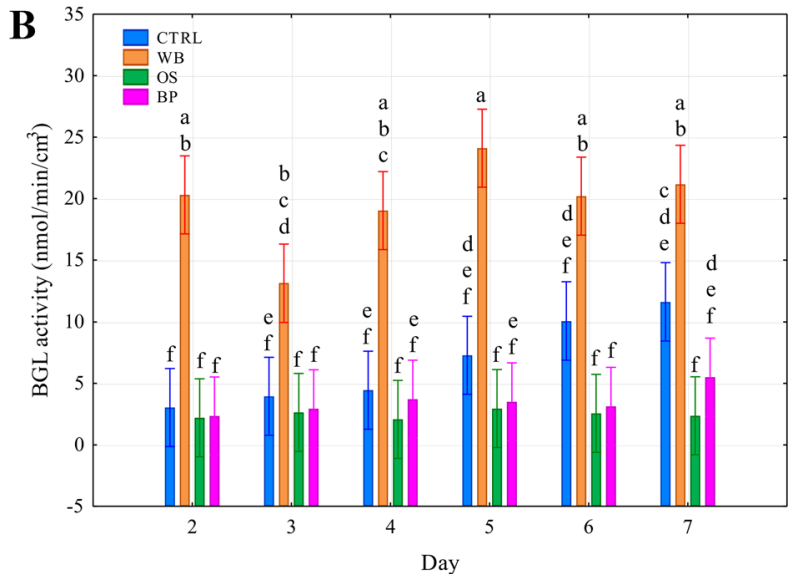

describe the statistical difference between each factor (calculated by Tukey test; see Table S5). CTRL Control, WB Durum wheat bran, $O S$ Oak sawdust, $B P$ Dried sugar beet pulp

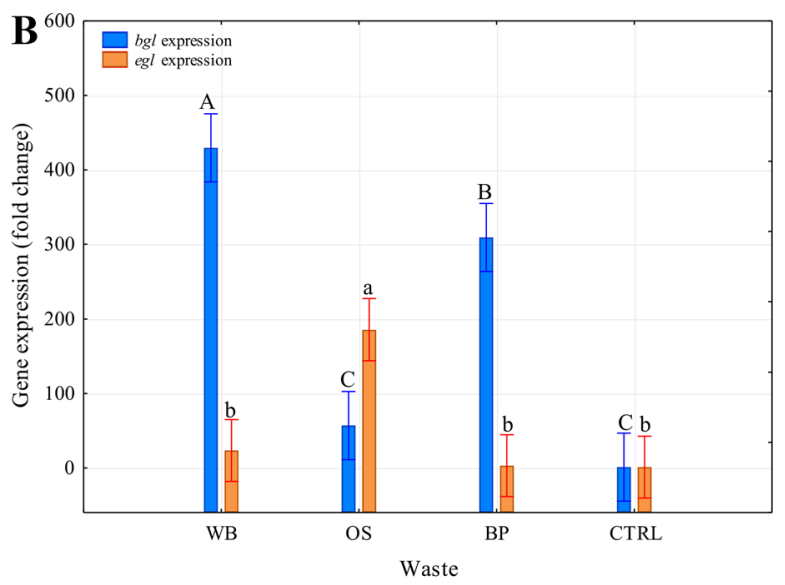

column describe the statistical difference between each factor (calculated by Tukey test; see Tables S6 and S7). CTRL Control, $W B$ Durum wheat bran, $O S$ Oak sawdust, $B P$ Dried sugar beet pulp

substrate induces cellulase production because of its solubility. In fact, a crucial transcription factor CLR-1, was discovered in Neurospora crassa which, during growth on microcrystalline cellulose, requires the utilization of cellobiose to promote the expression of the genes, which are involved in cellulase production (Coradetti et al. 2012). Furthermore, these strains are more active inside this substrate because the natural cellulose is insoluble and it is impossible for it to migrate across the fungal cell membrane; for this reason the fungi must break down the cellulose into simple sugars (for example, sophorose or cellobiose) 
which have the ability to pass through the membrane and induce cellulase production (Carle-Urioste et al. 1997). Petriella setifera showed the best utilization of the five carbon sources on the durum wheat bran (WB). This conclusion was confirmed from the results obtained in our previous paper (Oszust et al. 2018), in which the strains more readily decompose wastemedia rich in protein, $\mathrm{N}, \mathrm{P}, \mathrm{K}$ and easily accessible sugars (such as WB and BP). Filter paper (FPU) was positively affected by the pre-culture step because of the increase of the AWDD index for all the wastes in contrast to the control (Fig. 2). On the other hand, the powdered cellulose (AB) did not present any influence from the pre-culture stage, whereas the carboxymethylcellulose (CMC) and microcrystalline cellulose (VP) registered the opposite effect because the AWDD index was higher in the control than the wastes analysed. Our finding, concerning the utilization of the VP source, did not agreed with the paper of (Duff and Murrayh 1996). They found that the Avicel microcrystalline cellulose and wheat bran induced cellulase activity. This strong utilization of CB in WB and OS media may be related to the presence of cellooligosaccharides and the high content of $\mathrm{N}$ for WB waste, whereas for OS waste it may be related to the degradation of lignin. In a recent work of Janusz et al. (2018) it was shown that the role of the laccase enzyme may be carried out by other enzymes involved in quinine redox-cycling and the oxidation of ligninderived products. Moreover, Oriaran et al. (1988) found that the addition of glucose to the medium can lead to a reduction in the lignin content. The $490 / 750 \mathrm{~nm}$ ratio revealed that the best ratio appears in all analysed strains which are exposed on carboxymethylcellulose (CMC), furthermore, the different pre-cultured waste did not affect this ratio (Table 3). This result could relate to the step of preculturing on the three different waste for 30 days. In this phase, the fungi start the degradation of the lignin to obtain free-cellulose. When we transferred the mycelium in contact with CMC, the enzyme carboxymethylcellulase (CMCase) or endo-1,4- $\beta$-glucanase begin the degradation of CMC. The energy was obtained through this degradation could be use a little for the mycelium growing, a little for other pathways and other for the formation of ascus and ascospores or a second antimicrobial metabolite (Umehara et al. 1983) to overcome this stressful situation. The cellobiose (CB) did not permit the presence of very nice ratio (range 1.482-2.216) because the fungi degraded CB to get glucose. The higher concentration of glucose and cellobiose caused a stressful condition. On the other hand, we need to consider that in the $\mathrm{CB}$ condition the strains present no a nice ratio (this means that the metabolic activity is not efficient) but if we consider only the OD $750 \mathrm{~nm}$ (which measures the biomass development), all the strains present the high value than the other analysed waste (Fig. 2). This means that all the strains grew better in this good condition, but they need more energy because they need to adapt their metabolism to the new situation (before they were cultivated on lignocellulosic waste and after only $\mathrm{CB}$ ). For microcrystalline cellulose (VP), powdered cellulose (AB) and cellulose filter paper (FPU), the ratio was higher than the other two analysed carbon sources, this could relate to the structure of the cellulose. These three compounds have not an easy cellulose structure and the fungi to obtain free-cellulose, need so much energy to break the chemical bonds to obtain available carbon. Based on literature review, the comparison of $P$. setifera capabilities to commercially available biopreparations indicated a potential of this fungus in cellulose degrading pathway. In general, the preparation mixture contains cocktails of different enzymes, e.g. xylanase and endoglucanase from Trichoderma longibrachiatum (Celustar XL-Dyadic International Inc., Florida, USA), carboxymethylocellulase and endoglucanase from Penicillium funiculosum (Optimash $^{\text {TM }}$ VR, Genecor, San Fransisco, USA), pectinase and endoglucanase (Agropect pomace, Danisco Poland Sp. z o.o.) (Oszust et al. 2017). The results of presented study indicating that $P$. setifera is characterised by specific metabolic profile and suggesting that is able to synthetize complex of enzymes for degradation, which confirm potential of this fungus in application sector.

In conclusion, we may say that all $P$. setifera strains found an optimum growing condition within the control, durum wheat bran, and oak sawdust substrates. Especially, the pre-culture stage did not influence the balance between the metabolic activity and biomass development on substrate $\mathrm{CB}$ as a carbon source. Analysing each enzymatic activity separately, it was found that the total cellulase content (FPase; Fig. S3) did not exhibit a high activity and the results obtained were not statistically different between wastes. Wen et al. (2005) described the cellulase 
activity as species-specific and dependent on the substrates analysed. In another work, it is noted that the cellulase activity was affected positively by the wheat bran substrate (Duff and Murrayh 1996; Sun et al. 2008; Brijwani et al. 2010; Oberoi et al. 2010; Dhillon et al. 2011). A possible cause of the nonpresence of FPase activity is the presence of mineral substances that may have created a reaction with the medium, leading to the creation of inhibitory substances resulting in lower FPase activity (Oberoi et al. 2010). This low FPase activity may be related to the nature of the carbon source added to the medium (Dhillon et al. 2011) or to the energy-consuming process of enzyme production, so the fungus produces this enzyme only when it is required and utilizes plant polymers as energy and carbon sources (Amore et al. 2013), but, in our case, different lignocellulosic waste were added to each medium plus the Potato Dextrose Broth (PDB; this medium contains the convenient carbon source dextrose). Moreover, the induction of the gene expression of cellulase is linked to the presence of substrate polymers (e.g. cellobiose, gentiobiose, sophorose, etc.). On the other hand, the presence of easily available carbon sources (e.g. glucose and cellobiose) inhibits the expression of these genes and consequently, the activity of the enzyme significantly slows the global process of cellulose degradation. This phenomenon is called carbon catabolite repression (CCR) (Aro et al. 2005; Amore et al. 2013; Glass et al. 2013) and the derepression of gene expression is activated when the glucose concentration drops. In our experiment, it is possible that the FPase activity was affected by the glucose concentration in all media and that all $P$. setifera strains utilized the glucose through other low energy-consuming pathways to obtain energy and carbon sources. As for the total cellulase activity (FPase), P. setifera did not present a good ability to induce the activity of FPase in the control (PDB medium) and the three analysed wastes. Another important aspect provided by these results is that this fungus did not produce isoforms of this enzyme and therefore it lacked the ability to activate the production of this enzyme on different media (Duff and Murrayh 1996), or else these isoforms were not produced due to the presence of glucose inhibition. Another important aspect to consider is that it is possible that the lack of FPase activity is related to the concentration of cellobiose or cello-oligosaccharides because over time the addition of these two substances can lead to an increase in the activity of the enzyme (Sun et al. 2008). The activity of carboxymethylcellulase (CMCase) was detected in all the wastes and it was higher in the three analysed wastes than in the CTRL substrate (Fig. 4a). These results were confirmed by the results of other studies (Narasimha et al. 2006; Gao et al. 2008; Coradetti et al. 2012). Through Fig. 4, it may be concluded that the CMCase activity is higher for OS and BP wastes than it is for the control, and especially, the enzyme activity within the WB waste is increased from the 3rd day of the incubation period until the end of the experiment (Fig. 4b). The slow manifestation of CMCase activity in WB waste could be related to the lower concentration of cellulose (its concentration is 2.27-fold lower than BP waste and 5.57-fold lower than SD; see Table 2); in contrast, the higher CMCase activity appears in OS and BP wastes because of the high concentration of neutral detergent fibre (NDF), acid detergent fibre (ADF), and cellulose (CEL) (Table 1). The CMCase activity is induced by the presence of xylose, cellobioside, and microcrystalline cellulose. This enzyme attacks the low crystallinity areas of cellulose and this characteristic could relate to the high activity in OS and BP wastes (Fig. 4a). Through the correlation between the chemical characterization of the analysed wastes and the CMCase activity, any results that could be statistically significant ( $p$ value $>0.05$; Table 4 ) were not observed. In case of result correlations, it was observed that features like total nitrogen $\left(\mathrm{N}_{\mathrm{tot}}\right)$, non-fibre carbohydrates (NFC), crude protein (CP), and crude fat (CF) were correlated negatively, whereas NDF, ADF, and CEL were correlated positively to CMCase activity. These features are the principal characteristics of OS and BP wastes (see Fig. 4a and Table 4). In particular, the negative effect of starch on cellulase and $\beta$ glucosidase was confirmed by the work of Sun et al. (2008). The last analysed enzyme, $\beta$-glucosidase (BGL), produces a higher level of activity in WB waste (ca. $20 \mathrm{nmol} / \mathrm{min} / \mathrm{cm}^{3}$; Fig. 5a), and the level of the activity was higher for the duration of the experiment (Fig. 5b). Higher activity level may be related to four principal aspects: an increased presence of inducers (transglycosylation) (Suto and Tomita 2001), the accumulation of cellobiose and glucose inhibition (carbon catabolite repression-CCR) and the possibility of the existence of isoforms or the presence of more than one gene that encodes for the $\beta$ - 
glucosidase enzyme, and the mineral composition of wheat bran medium (Oberoi et al. 2010). This higher level of activity could be affected by the presence of a relevant concentration of cello-oligosaccharides, which are degraded into substances that induce cellulase production. After obtaining these inducing molecules, they migrate inside the cell inducing the transcription of the genes involved in cellulase production. As a result of cellulose degradation, free glucose is produced which causes the CCR phenomenon. This higher $\beta$-glucosidase (BGL) production is connected with glucose and cellobiose as positive "inducers", because of its inhibition activity (Amore et al. 2013) and its conversion by the cellulase-inducer through the transglycosylation pathway. Another possible explanation is the presence of more than one gene that encodes BGL enzyme. In fact, researchers have detected two bgl genes in Trichoderma reesei and Neurospora crassa (Amore et al. 2013). Durum wheat bran (WB) waste presented a higher level of BGL activity than the other wastes. These findings may be related to the lower content of cellulose $(7.70 \pm 0.30 \%$ of total solids, correlation coefficient was $-0.714, p$ value 0.493 , Tables 2,4 ) and a higher content of nitrogen $(2.94 \pm 0.11 \%$ of total solids, correlation coefficient was $0.874, p$ value 0.323 , Tables 1,2 ) because this element can positively influence BGL activity and it helps to stimulate the initial stage of litter degradation (Kellner et al. 2010; Zhao et al. 2013). The increase in CMCase and BGL activities during the experiment may be justified by the fact that the biosynthesis of lignocellulolytic enzymes increased with the decrease of cellulose available (Kadimaliev et al. 2003).

The ratio of $\beta$-glucosidase activity to filter paper activity has been calculated elsewhere. This ratio is ideal when it presents a range of $0.12-1.5$ (Wen et al. 2005; Ahamed and Vermette 2008; Dhillon et al. 2011) and this ratio depends on the affinity between the enzyme and the substrate, and the type of substrate. In our experiment, this ratio was 1.35 and 0.17 for durum wheat bran (WB) and oak sawdust (OS), respectively. This rate explains that the $\beta$-glucosidase produced by $P$. setifera was sufficient to hydrolyse the cellobiose to glucose only in WB and OS wastes.

The relative quantification of the genes involved in cellulose degradation on the wheat bran medium resulted in a high gene expression profile for the hydrolytic enzymes of Aspergillus oryzae (Sun et al.
2008). In contrast, for our experiment, only the $c b h$ gene is not expressed inside these analysed wastes. The lack of expression of this gene is related to the much lower FPase activity (Fig. S3) (Rahman et al. 2009). The repression of the $c b h$ and $e g l$ genes may be observed in glucose-containing media (Amore et al. 2013), and this phenomenon ceases when the concentration of glucose falls. The expression of the remaining genes, $e g l$, and $b g l$ starts from the 3rd day of the incubation time (Fig. 6a). The fact that enzymatic activities begin 1 day before the expression of its genes is related to the possible existence of other isoforms of these enzymes (several filamentous fungi have the ability to express different BGL isoforms as a function of the prevailing culture conditions or carbon sources) (Singhania et al. 2013) or the enzymatic activities were expressed through other genes. In fact, in Hypocrea jecorina (T. reesei) (Sordariomycetes), 3 $\mathrm{egl}$ genes are found for the first and $5 \mathrm{egl}$ and $2 \mathrm{bgl}$ genes for the second fungus (Gruno et al. 2004; Murphy et al. 2013). The egl expression (Fig. 6a) presents higher value at the beginning and, after the 3rd day, the value decreases to zerofold at the end of the experiment. The decrease in the fold change for this gene could be related to the presence of cellobiose and glucose inside the media which leads to an inhibition of the $e g l$ expression. In the case of Figs. 4 and 6 , the confirmation of the activity and expression of the endoglucanase gene for the OS waste were observed, but this did not confirm the trend of the BP waste. The absence of a correlation between the enzymatic activity and gene expression could be related to the expression of a different gene from the one that was analysed, this is possible in a fungus that possesses more genes that encode for the same enzymes (Gruno et al. 2004; Murphy et al. 2013), or perhaps, there exists on the Petriella genome alternative splicing events that result in the production of multiple isoforms that function at certain stages of development, or under certain culture conditions or for particular carbon sources (Cai et al. 1999; Olsson et al. 2003; Bustin et al. 2009; Hatakka and Hammel 2010; Amore et al. 2013; Singhania et al. 2013; Li et al. 2016). Tirado-González et al. (2016) found that when the fungi grow in different conditions from the optimum condition of growth, they can modify the gene expression to obtain the enzyme or isoforms of the same enzyme. It is particularly noteworthy that the expression of the $e g l$ gene is ca. 100-fold higher in the 
oak sawdust. This finding is positively correlated with the ratio of cellulose to lignin content and negatively with the ratio of lignin to hemicellulose content (Table 2). The higher expression of this gene could be connected with the glucose content because glucose induces lignin degradation and consequently, cellulose becomes more available (Oriaran et al. 1988). On the other hand, the expression of the $b g l$ gene was negatively correlated with the neutral detergent fibre (it indicates the content of hemicellulose, cellulose, lignin) and cellulose content. This negative correlation may be explained by the requirement to have cellobiose available. The accessibility of this convenient carbon source is given by lower content of lignin (this leads to higher cellulose availability) and lower content of cellulose (because through its degradation the microorganisms obtain the cellobiose).

Analysing together the enzymatic activities and the gene expression, the lower activity of FPase and CMCase was observed and it may be related to the inhibition product from the hydrolysis of cellulose, i.e. cellobiose and glucose (Andrić et al. 2010; Murphy et al. 2013; Teugjas and Väljamäe 2013); on the other hand, the higher activity of BGL (300- to 400-fold change) could be related to the transglycosylation reaction. This reaction permits the transfer of glucose or cellobiose to yield different di-, tri-, and oligosaccharides (Andrić et al. 2010; Glass et al. 2013), thus relieving the product inhibition of FPase and CMCase. This phenomenon was studied in Penicillium piceum (Gao et al. 2013), A. oryzae (He et al. 2013) and Fusarium oxysporum (Christakopoulos et al. 1994).

\section{Conclusions}

In summary, the present study revealed that preculturing on a lignocellulolytic waste of $P$. setifera filamentous fungus negatively affects the utilization of the microcrystalline cellulose and carboxymethylcellulose. In contrast, the implementation of pre-culturing increased the utilization of filter paper and cellobiose activity. The activity of FPase and the expression of the $c b h$ gene (unlike the other two analysed enzymes and genes) were not activated in $P$. setifera cells by substrates used in the study. On the other hand, the high activity of CMCase and BGL and also the expression of $b g l$ and $e g l$ have indicated a possible pathway for cellulose degradation in the analysed conditions. These biological findings confirm that $P$. setifera is capable of living and growing, especially on the medium with durum wheat bran and oak sawdust, in the presence of plant biomass and an inhibitor (i.e. cellobiose and glucose) thus confirming that this fungus can degrade cellulose and is partially engaged into lignin degradation.

Acknowledgments Equipment used in this study was supported by European Union funds-Operational Program Development of Eastern Poland 2007-2013.

Open Access This article is distributed under the terms of the Creative Commons Attribution 4.0 International License (http:// creativecommons.org/licenses/by/4.0/), which permits unrestricted use, distribution, and reproduction in any medium, provided you give appropriate credit to the original author(s) and the source, provide a link to the Creative Commons license, and indicate if changes were made.

\section{References}

Ahamed A, Vermette P (2008) Enhanced enzyme production from mixed cultures of Trichoderma reesei RUT-C30 and Aspergillus niger LMA grown as fed batch in a stirred tank bioreactor. Biochem Eng J 42:41-46. https://doi.org/10. 1016/j.bej.2008.05.007

Ahmed S, Bashir A, Saleem H et al (2009) Production and purification of cellulose- degrading enzymes from a filamentous fungus Trichoderma harzianum. Pak $\mathrm{J}$ Bot 41:1411-1419

Amore A, Giacobbe S, Faraco V (2013) Regulation of cellulase and hemicellulase gene expression in Fungi. Curr Genom 14:230-249. https://doi.org/10.2174/13892029113140 40002

Andrić P, Meyer AS, Jensen PA, Dam-Johansen K (2010) Reactor design for minimizing product inhibition during enzymatic lignocellulose hydrolysis: I. Significance and mechanism of cellobiose and glucose inhibition on cellulolytic enzymes. Biotechnol Adv 28:308-324. https://doi. org/10.1016/j.biotechadv.2010.01.003

Arnold K, Bordoli L, Kopp J, Schwede T (2006) The SWISSMODEL workspace: a web-based environment for protein structure homology modelling. Bioinformatics 22:195-201. https://doi.org/10.1093/bioinformatics/bti770

Aro N, Pakula T, Penttilä M (2005) Transcriptional regulation of plant cell wall degradation by filamentous fungi. FEMS Microbiol Rev 29:719-739. https://doi.org/10.1016/j. femsre.2004.11.006

Barbi F, Bragalini C, Vallon L et al (2014) PCR primers to study the diversity of expressed fungal genes encoding lignocellulolytic enzymes in soils using high-throughput sequencing. PLoS ONE 9:1-22. https://doi.org/10.1371/ journal.pone.0116264

Biasini M, Bienert S, Waterhouse A et al (2014) SWISSMODEL: modelling protein tertiary and quaternary 
structure using evolutionary information. Nucleic Acids Res 42:W252-W258. https://doi.org/10.1093/nar/gku340

Brijwani K, Oberoi HS, Vadlani PV (2010) Production of a cellulolytic enzyme system in mixed-culture solid-state fermentation of soybean hulls supplemented with wheat bran. Process Biochem 45:120-128. https://doi.org/10. 1016/j.procbio.2009.08.015

Bustin SA, Benes V, Garson JA et al (2009) The MIQE guidelines: minimum information of publication of Quantitative Real-Time PCR experiments. Clin Chem 55:3605-3613. https://doi.org/10.1373/clinchem.2008.112797

Cai YJ, Chapman SJ, Buswell JA, Chang S-T (1999) Production and distribution of endoglucanase, cellobiohydrolase, and $\beta$ - glucosidase components of the cellulolytic system of Volvariella volvacea, the edible straw mushroom. Appl Environ Microbiol 65:553-559

Camassola M, Dillon AJP (2007) Production of cellulases and hemicellulases by Penicillium echinulatum grown on pretreated sugar cane bagasse and wheat bran in solid-state fermentation. J Appl Microbiol 103:2196-2204. https:// doi.org/10.1111/j.1365-2672.2007.03458.x

Carle-Urioste JC, Escobar-Vera J, El-Gogary S et al (1997) Cellulase induction in Trichoderma reesei by cellulose requires its own basal expression. J Biol Chem 272:10169-10174. https://doi.org/10.1074/jbc.272.15.10169

Christakopoulos P, Goodenough PW, Kekos D et al (1994) Purification and characterization of an extracellular betaglucosidase with transglycosylation and exo-glucosidase activities from Fusarium oxysporum. Eur J Soil Biol 224:379-385. https://doi.org/10.1111/j.1432-1033.1994. 00379.x

Coradetti ST, Craig JP, Xiong Y et al (2012) Conserved and essential transcription factors for cellulase gene expression in ascomycete fungi. Proc Natl Acad Sci 109:7397-7402. https://doi.org/10.1073/pnas.1200785109

Corporation L (1998) A guide to Kjeldahl nitrogen determination methods and apparatus. Texas, USA

Danon M, Chen Y, Hadar Y (2010) Ascomycete communities associated with suppression of Sclerotium rolfsii in compost. Fungal Ecol 3:20-30. https://doi.org/10.1016/j. funeco.2009.05.003

Deschamps F, Huet MC (1984) Beta-glucosidase production in agitated solid fermentation, study of its properties. Biotech Lett 6:451-456. https://doi.org/10.1007/BF00129308

Dhillon GS, Oberoi HS, Kaur S et al (2011) Value-addition of agricultural wastes for augmented cellulase and xylanase production through solid-state tray fermentation employing mixed-culture of fungi. Ind Crops Prod 34:1160-1167. https://doi.org/10.1016/j.indcrop.2011.04.001

Duff SJB, Murrayh WD (1996) Bioconversion of forest products industry waste cellulosics to fuel ethanol: a review. Bioresour Technol 55:1-33. https://doi.org/10.1016/09608524(95)00122-0

Edwards IP, Upchurch RA, Zak DR (2008) Isolation of fungal cellobiohydrolase I genes from sporocarps and forest soils by PCR. Appl Environ Microbiol 74:3481-3489. https:// doi.org/10.1128/AEM.02893-07

Fracc M, Gryta A, Oszust K, Kotowicz N (2016) Fats and accurate micropalte method (Biolog MT2) for detection of Fusarium fungicides resistance/sensitivity. Front Microbiol 7:1-17. https://doi.org/10.3389/fmicb.2016.00489
Gao J, Weng H, Zhu D et al (2008) Production and characterization of cellulolytic enzymes from the thermoacidophilic fungal Aspergillus terreus M11 under solid-state cultivation of corn stover. Bioresour Technol 99:7623-7629. https://doi.org/10.1016/j.biortech.2008.02.005

Gao L, Gao F, Zhang D et al (2013) Purification and characterization of a new $\beta$-glucosidase from Penicillium piceum and its application in enzymatic degradation of delignified corn stover. Bioresour Technol 147:658-661. https://doi. org/10.1016/j.biortech.2013.08.089

Glass NL, Schmoll M, Cate JHD, Coradetti S (2013) Plant cell wall deconstruction by Ascomycete fungi. Annu Rev Microbiol 67:477-498. https://doi.org/10.1146/annurevmicro-092611-150044

Gruno M, Väljamäe P, Pettersson G, Johansson G (2004) Inhibition of the Trichoderma reesei cellulases by cellobiose is strongly dependent on the nature of the substrate. Biotechnol Bioeng 86:503-511. https://doi.org/10.1002/ bit. 10838

Guex N, Peitsch MC, Schwede T (2009) Automated comparatice protein structure modelling with SWISS-MODEL and Swiss-Pdb Viewer: a historical perspective. Electrophoresis 30:S162-S173. https://doi.org/10.1002/elps.200900140

Hammel KE (1997) Fungal degradation of lignin. In: Cadisch G, Giller KE (eds) Driven by nature: plant litter quality and decomposition. CAB INTERN, pp 33-45

Hankin L, Anagnostakis SL (1977) Solid media containin carboxymethylcellulose to detect CX cellulose activity of micro-organisms. J Gen Microbiol 98:109-115. https://doi. org/10.1099/00221287-98-1-109

Hannula SE, De Boer W, Baldrian P, Van Veen JA (2013) Effect of genetic modification of potato starch on decomposition of leaves and tubers and on fungal decomposer communities. Soil Biol Biochem 58:88-98. https://doi.org/10. 1016/j.soilbio.2012.11.008

Hatakka A, Hammel KE (2010) Fungal biodegradation of lignocelluloses. In: Hofrichter M (ed) International Journal of Biochemistry and Molecular Biology, Second. Springer, Berlin, pp 319-340

He H, Qin Y, Chen G et al (2013) Two-step purification of a novel $\beta$-glucosidase with high transglycosylation activity and another hypothetical $\beta$-glucosidase in Aspergillus oryzae HML366 and enzymatic characterization. Appl Biochem Biotechnol 169:870-884. https://doi.org/10. 1007/s12010-012-9936-9

Ilmén M, Saloheimo A, Onnela M-L, Penttilä ME (1997) Regulation of cellulase gene expression in the filamentous fungus Trichoderma reesei. Appl Environ Microbiol 63:1298-1306

Janusz G, Mazur A, Wielbo J et al (2018) Comparative transcriptomic analysis of Cerrena unicolor revealed differential expression of genes engaged in degradation of various kinds of wood. Microbiol Res 207:256-268. https://doi.org/10.1016/j.micres.2017.12.007

Ju L-K, Afolabi OA (1999) Wastepaper hydrolysates as soluble inducing substrate for cellulase production in continuous culture of Trichoderma reesei. Biotechnol Prog 15:91-97. https://doi.org/10.1021/bp980116n

Kadimaliev DA, Revin VV, Atykyan NA, Samuilov VD (2003) Effect of wood modification on lignin consumption and synthesis of lignolytic enzymes by the fungus Panus 
(Lentinus) tigrinus. Appl Biochem Microbiol 39:488-492. https://doi.org/10.1023/A:1025448703138

Kellner H, Zak DR, Vandenbol M (2010) Fungi unearthed: transcripts encoding lignocellulolytic and chitinolytic enzymes in forest soil. PLoS ONE 5:1-7. https://doi.org/ 10.1371/journal.pone.0010971

Kiefer F, Arnold K, Künzli M et al (2009) The SWISS-MODEL repository and associated resources. Nucleic Acids Res 37:D387-D392. https://doi.org/10.1093/nar/gkn750

King BC, Donnelly MK, Bergstrom GC et al (2009) An optimized microplate assay system for quantitative evaluation of plant cell wall-degrading enzyme activity of fungal culture extracts. Biotechnol Bioeng 102:1033-1044. https://doi.org/10.1002/bit.22151

Lackner M, De Hoog GS (2011) Parascedosporium and its relatives: phylogeny and ecological trends. IMA Fungus 2:39-48. https://doi.org/10.5598/imafungus.2011.02.01.07

Li N, Kunitake E, Aoyama M et al (2016) McmA-dependent and -independent regulatory systems governing expression of ClrB-regulated cellulase and hemicellulase genes in Aspergillus nidulans. Mol Microbiol 102:810-826. https:// doi.org/10.1111/mmi.13493

Maeda H, Sano M, Maruyama Y et al (2004) Transcriptional analysis of genes for energy catabolism and hydrolytic enzymes in the filamentous fungus Aspergillus oryzae using cDNA microarrays and expressed sequence tags. Appl Microbiol Biotechnol 65:74-83. https://doi.org/10. 1007/s00253-004-1608-4

Mandels M, Andreotti R, Roche C (1976) Measurement of saccharifying cellulase. Biotechnol Bioeng Symp 6:21-33

Martínez ÁT, Speranza M, Ruiz-Dueñas FJ et al (2005) Biodegradation of lignocellulosics: microbial, chemical, and enzymatic aspects of the fungal attack of lignin. Int Microbiol 8:195-204

Mathieu Y, Gelhaye E, Dumarçay S et al (2013) Selection and validation of enzymatic activities as functional markers in wood biotechnology and fungal ecology. J Microbiol Methods 92:157-163. https://doi.org/10.1016/j.mimet. 2012.11.017

Mikiashvili NA, Isikhuemhen OS, Ohimain EI (2011) Lignin degradation, ligninolytic enzymes activities and exopolysaccharide production by Grifola frondosa strains cultivated on oak sawdust. Braz J Microbiol 42:1101-1108. https://doi.org/10.1590/S1517838220110003000031

More TT, Yan S, Tyagi RD, Surampalli RY (2010) Potential use of filamentous fungi for wastewater sludge treatment. Bioresour Technol 101:7691-7700. https://doi.org/10. 1016/j.biortech.2010.05.033

Murphy L, Bohlin C, Baumann MJ et al (2013) Product inhibition of five Hypocrea jecorina cellulases. Enzyme Microb Technol 52:163-169. https://doi.org/10.1016/j. enzmictec.2013.01.002

Narasimha G, Sridevi A, Buddolla V, Subhosh CM, Rajasekhar RB (2006) Nutrient effects on production of cellulolytic enzymes by Aspergillus niger. Afr J Biotechnol 5:472-476

Niranjane AP, Madhou P, Stevenson TW (2007) The effect of carbohydrate carbon sources on the production of cellulase by Phlebia gigantea. Enzyme Microb Technol 40:1464-1468. https://doi.org/10.1016/j.enzmictec.2006.10.041
Oberoi HS, Chavan Y, Bansal S, Dhillon GS (2010) Production of cellulases through solid state fermentation using kinnow pulp as a major substrate. Food Bioprocess Technol 3:528-536. https://doi.org/10.1007/s11947-008-0092-8

Oleszek M, Krzemińska I (2017) Enhancement of biogas production by co-digestion of maize silage with common goldenrod rich in biologically active compounds. BioResource 12:704-714

Olsson L, Christensen TMIE, Hansen KP, Palmqvist EA (2003) Influence of the carbon source on production of cellulases, hemicellulases and pectinases by Trichoderma reesei Rut C-30. Enzyme Microb Technol 33:612-619. https://doi. org/10.1016/S0141-0229(03)00181-9

Oriaran TP, Labosky P, Royse DJ (1988) Lignin degradation capabilities of Pleurotus ostreatus, Lentinula edodes and Phanerochaete chrysosporium. Wood Fiber Sci 21:183-192

Oszust K, Pawlik A, Janusz G et al (2017) Characterization and influence of a multi-enzymatic biopreparation for biogas yield enhancement. BioResource 12:6187-6206

Oszust K, Panek J, Pertile G et al (2018) Metabolic and genetic properties of Petriella setifera precultured on waste. Front Microbiol 9:1-10. https://doi.org/10.3389/fmicb.2018.00115

Pertile G, Panek J, Oszust K et al (2018) Intraspecific functional and genetic diversity of Petriella setifera. PeerJ 6:1-24. https://doi.org/10.7717/peerj.4420

Pfaffl MW (2004) Quantification strategies in real-time PCR. In: Bustin SA (ed) A-Z of quantitative PCR. International University Line, La Jolla, pp 87-112

Pinzari F, Reverberi M, Piñar G et al (2014) Metabolic profiling of Minimedusa polyspora (Hotson) Weresub \& P. M. LeClair, a cellulolytic fungus isolated from Mediterranean maquis, in southern Italy. Plant Biosyst 148:333-341

Pinzari F, Ceci A, Abu-Samra N et al (2016) Phenotype MicroArray ${ }^{\mathrm{TM}}$ system in the study of fungal functional diversity and catabolic versatility. Res Microbiol 167:710-722. https://doi.org/10.1016/j.resmic.2016.05.008

Rahman Z, Shida Y, Furukawa T et al (2009) Application of Trichoderma reesei cellulase and xylanase promoters through homologous recombination for enhanced production of extracellular beta-glucosidase I. Biosci Biotechnol Biochem 73:1083-1089. https://doi.org/10.1271/bbb. 80852

Raulo R, Kokolski M, Archer DB (2016) The roles of the zinc finger transcription factors $\mathrm{X} \ln \mathrm{R}, \mathrm{ClrA}$ and $\mathrm{ClrB}$ in the breakdown of lignocellulose by Aspergillus niger. AMB Express 6:1-12. https://doi.org/10.1186/s13568-016-0177-0

Sánchez C (2009) Lignocellulosic residues: biodegradation and bioconversion by fungi. Biotechnol Adv 27:185-194. https://doi.org/10.1016/j.biotechadv.2008.11.001

Singhania RR, Patel AK, Sukumaran RK et al (2013) Role and significance of beta-glucosidases in the hydrolysis of cellulose for bioethanol production. Bioresour Technol 127:500-507. https://doi.org/10.1016/j.biortech.2012.09. 012

Stevenson L, Phillips F, O'Sullivan K, Walton J (2012) Wheat bran: its composition and benefits to health, a European perspective. Int J Food Sci Nutr 63:1001-1013. https://doi. org/10.3109/09637486.2012.687366

Sun X, Liu Z, Qu Y, Li X (2008) The effects of wheat bran composition on the production of biomass-hydrolyzing enzymes by Penicillium decumbens. Appl Biochem 
Biotechnol 146:119-128. https://doi.org/10.1007/s12010007-8049-3

Suto M, Tomita F (2001) Induction and catabolite repression mechanisms of cellulase in fungi. $\mathrm{J}$ Biosci Bioeng 92:305-311. https://doi.org/10.1016/S13891723(01)80231-0

Suzuki H, Igarashi K, Samejima M (2008) Real-time quantitative analysis of carbon catabolite derepression of cellulolytic genes expressed in the basidiomycete Phanerochaete chrysosporium. Appl Microbiol Biotechnol 80:99-106. https://doi.org/10.1007/s00253-008-1539-6

Taha M, Kadali KK, Al-Hothaly K et al (2015) An effective microplate method (Biolog MT2) for screening native lignocellulosic-straw-degrading bacteria. Ann Microbiol 65:2053-2064. https://doi.org/10.1007/s13213-015-1044$\mathrm{y}$

Teugjas H, Väljamäe P (2013) Product inhibition of cellulases studied with ${ }^{14} \mathrm{C}$-labeled cellulose substrates. Biotechnol Biofuels 6:104. https://doi.org/10.1186/1754-6834-6-104

Tirado-González DN, Jáuregui-Rincón J, Tirado-Estrada GG et al (2016) Production of cellulases and xylanases by white-rot fungi cultured in corn stover media for ruminant feed applications. Anim Feed Sci Technol 221:147-156. https://doi.org/10.1016/j.anifeedsci.2016.09.001

Umehara K, Nakahara K, Kiyoto S et al (1983) Studies on WF3161, a neew antitumor antibiotic. J Antibiot 36:478-483. https://doi.org/10.1016/j.fbr.2007.09.001

Weber CF, Zak DR, Hungate BA et al (2011) Responses of soil cellulolytic fungal communities to elevated atmospheric $\mathrm{CO}_{2}$ are complex and variable across five ecosystems.
Environ Microbiol 13:2778-2793. https://doi.org/10.1111/ j.1462-2920.2011.02548.x

Wen Z, Liao W, Chen S (2005) Production of cellulase/ß-glucosidase by the mixed fungi culture Trichoderma reese $i$ and Aspergillus phoenicis on dairy manure. Process Biochem 40:3087-3094. https://doi.org/10.1016/j.procbio. 2005.03.044

Woodsmall RM, Benson DA (1993) Information resources at the National Center for Biotechnology Information. Bull Med Libr Assoc 81:282-284. https://doi.org/10.1104/pp. 104.058842.1280

Yamakawa Y, Endo Y, Li N et al (2013) Regulation of cellulolytic genes by McmA, the SRF-MADS box protein in Aspergillus nidulans. Biochem Biophys Res Commun 431:777-782. https://doi.org/10.1016/j.bbrc.2013.01.031

Yuan Z, Chen L (2014) The role of endophytic fungal individuals and communities in the decomposition of Pinus massoniana needle litter. PLoS ONE 9:1-11. https://doi. org/10.1371/journal.pone.0105911

Zhao XH, Wang W, Wei DZ (2013) Identification of Petriella setifera LH and characterization of its crude carboxymethyl cellulase for application in denim biostoning. J Microbiol 51:82-87. https://doi.org/10.1007/s12275013-2370-z

Publisher's Note Springer Nature remains neutral with regard to jurisdictional claims in published maps and institutional affiliations. 